\title{
CONSERVATION OF MILITARY HERITAGE: THE DEFENSIVE WALL OF CARTAGENA DE INDIAS, COLOMBIA
}

\author{
A. GUIDA, A. PAGLIUCA \& C. FATTORE \\ Department of European and Mediterranean Cultures: Architecture, Environment, \\ Cultural Heritage (DiCEM), University of Basilicata, Italy.
}

\begin{abstract}
The city of Cartagena de Indias (in the north of Colombia) boasts the largest and one of the most complete military defence systems of South America. Defined as 'the Pearl of the Caribbean' for its colonial characteristics and for its strategic location, it was the unquestioned leader in the routes of exploration of the West Indies. It is an example of the Italian and Spanish school of military engineering; it was conceived and designed by Battista Antonelli and built by his cousin Cristobal de Roda. Both of them contributed to the development of the system called 'abaluartado', typical of Central and South America, opening the ways to modern military systems. During 1700 reforms were enacted to strengthen the fortifications in Cartagena de Indias, which required significant changes to the characteristics of the walls. In 1966, the Spanish historian Juan Manuel Zapatero wrote a series of guidelines for the preservation of those walls. The walls have a simple and regular shape in which each block, with its geometric variation, forms the thickness of the wall, realized using a local stone called 'caliza'; this stone is of coral origin and rich in water. The preservation of a monument is not just its own conservation, in recognition of its historical and cultural value or in the characterization of its degradation. A monument could be used by the people, with a new awareness, that will ensure the survival - over time - of the historical memory of the past, going over the logic of the 'crystallization' of the monument in a museum of itself.

Keywords: conservation, defensive system, historical analysis, preservation, technological characterization.
\end{abstract}

\section{INTRODUCTION}

The city of Cartagena de Indias, located in the northern part of Colombia, boasts the largest and most complete military defence systems of South America. Thanks to this heritage, it is considered one of the most important cities for us to understand the origin and evolution of military architecture and its typologies in South America. Defined as 'the Pearl of the Caribbean' for its colonial shape and strategic location, it was the unquestioned leader in the routes of exploration of the West Indies.

Founded in 1533 by Pedro de Heredia, for a long time it was dominated by the Spanish. Soon it became the object of attack from French, English and Dutch pirates, interested in goods and gold that came from Chile and Peru; in fact, the port of Cartagena de Indias was a strategic point for European commercial trade [1]. A very famous attack was that by the French pirate Robert Baal in 1544; in fact, at that time the city and the bay still did not have a defensive system. It was repeatedly attacked and destroyed even by English pirates John Hawkins and Francis Drake in the 16th century.

\footnotetext{
$\underset{\text { CoNrerence }}{\mathrm{WIT}}$ This paper is part of the proceedings of the 3rd International Conference on Defence Sites: Heritage and Future (Defence Heritage 2016)

www.witconferences.com
} 


\section{THE DEFENSIVE SYSTEM}

As mentioned earlier, the wall of Cartagena is one of the most complete examples of the defence system called 'abaluartado' (Fig. 1) developed mostly in Central and South America. It is an example of the Italian and Spanish school of military engineering, designed by Battista Antonelli and built later by his cousin Cristòbal de Roda, during 1600.

Battista Antonelli was at the Court of Philip II of Spain from 1570. He designed the fortress on the Strait of Magellan, with an unappreciative defence system. In 1586 he returned to Central America and in 1599 designed (Fig. 2) the defence plan of the historic centre of Cartagena [1]; the first element to be designed was the 'Fuerte del Boquerón' (today called 'San Sebastian de Pastellito'), built to protect the entrance of the bay.

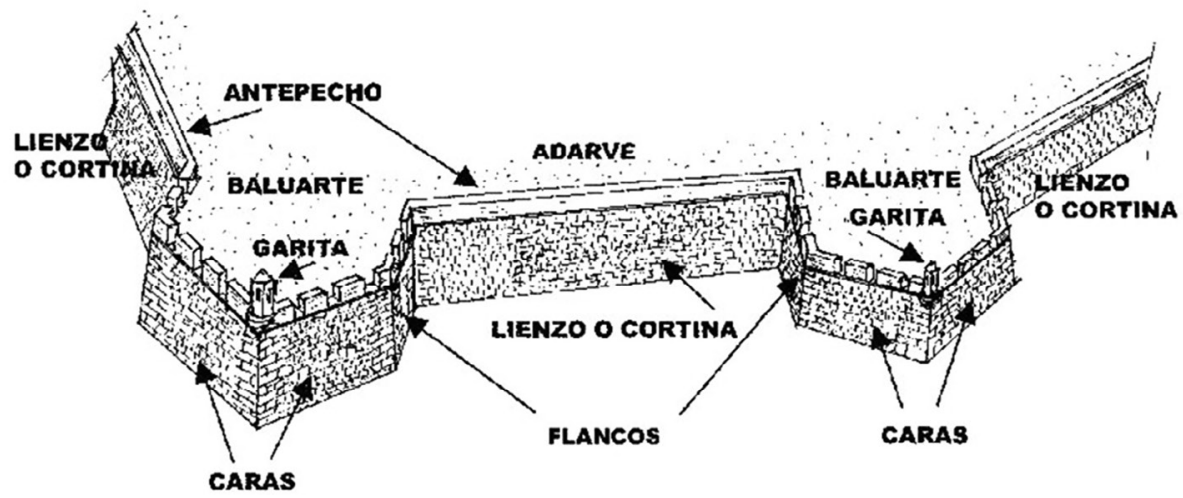

Figure 1: 'Abaluartado' defence system.

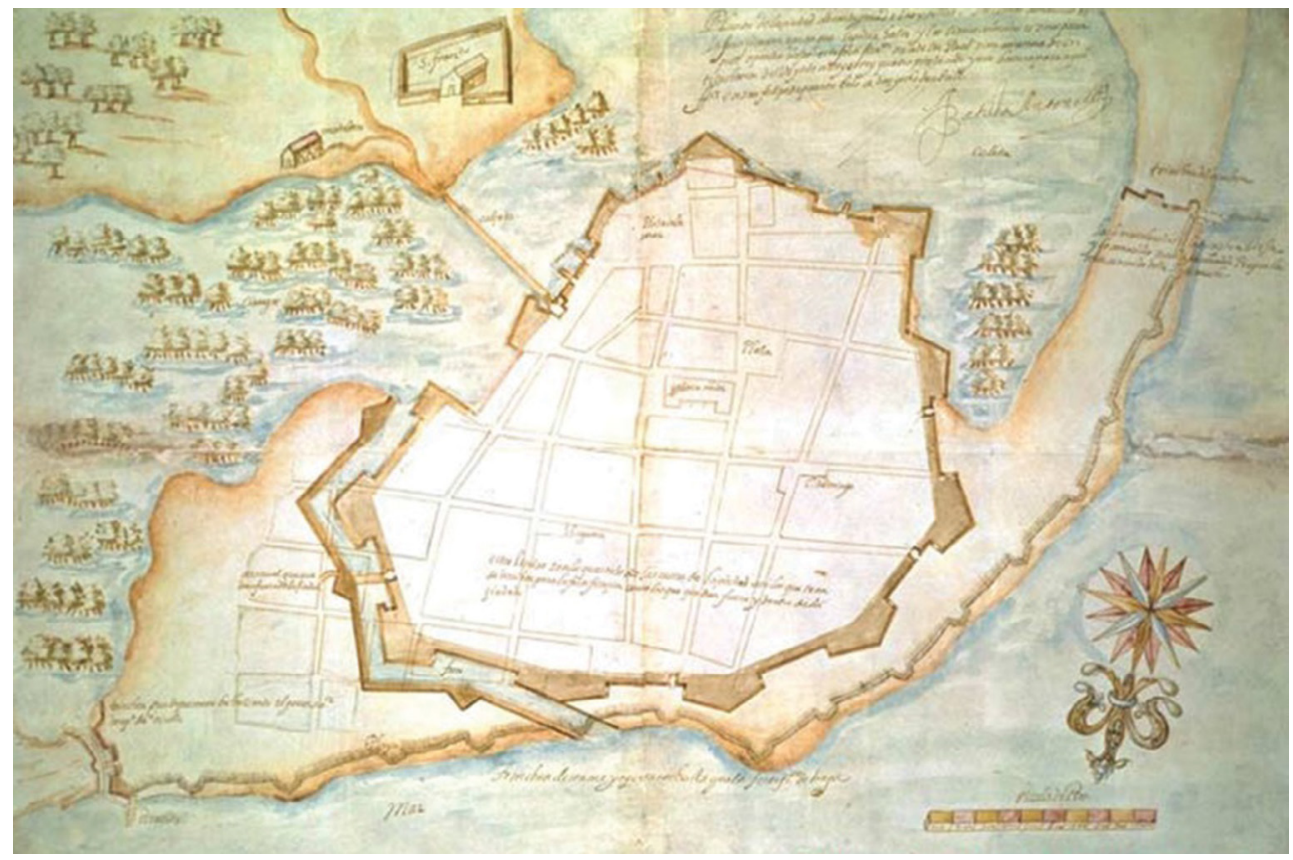

Figure 2: Antonelli's plan of Cartagena defence system (1599). 




Figure 3: Wall composition.

The defence system 'abaluartado' is characterized by a 'baluarte' (bastion), a German word that means 'construction of earth and wood quickly done'. This bastion has the task of defending the medieval castles and the strategic entrance to the city.

The bastion with a pentagon shape connects two parts of the wall, where heavy artillery is placed and where the largest concentration of soldiers is found; it was characterized by a typical battlement of the medieval fortress but redesigned according to the new needs. There are no more high and slender towers, but short and squat bastions, with an average height of $8 \mathrm{~m}$ that reached $9 \mathrm{~m}$ in some parts.

The wall section is composed of three significant layers (Fig. 3): the first layer has a variable thickness visible from the outside (tilted, tapered towards the top, so as not to allow the enemy to easily pass through the walls) consisting of stone blocks called 'caliza' [2]. A 
second inner layer (where the guns were positioned), which had the function of a counterwall, with lesser thickness than the first layer, and finally a third inner layer to the other two (central one), where the buttresses were placed as high as the first outer layer.

In this part of the wall there were sand, aggregates and waste materials that allowed to dissipate the energy of the cannon shot which the wall received when under attack.

The handbook of Cristobal de Rojas, 'Teórica y Práctica de Fortificaciones conforme a las medidas y defensas destos tiempos, repartida en tres partes' (1598), which explains the evolution of Renaissance military systems, could help to better understand the construction techniques over time.

\section{TECHNOLOGICAL CHARACTERIZATION OF THE WALL}

The wall is compact, entire and in regular layers (Fig. 4) in which each block (local stone called 'caliza') forms the thickness of the wall. It was built according to the ancient technique of 'isodoma' ('opus isodomum'), characterized by blocks of equal height and shape, well worked and arranged in horizontal lines with regular and homogeneous height; each block of the same line is offset with respect to those below [3]; the blocks are connected by mortar (Fig. 5).

The stone blocks are composed mainly of calcium carbonate (CaCO3) and magnesite (MgCO3) in smaller amounts; it is rich in water and has a whitish colour. This stone is found in the tropical areas where it is used in the construction sector (civil, military and religious purpose).

In Cartagena de Indias it was extracted mainly in the quarries of the island of Tierrabomba, birthplace of an important industrial system (extraction, processing and transportation).

The stone was quarried using explosives, then baked in kilns with a circular shape; the baking temperature was about $900 / 1000^{\circ} \mathrm{C}$ [3].

After baking, the kiln was left closed for three days (to cool the stone), then it was opened and the stones were selected for cutting (using saws or acids) to realize the blocks with a minimum size of $50 \times 70 \times 50(\mathrm{~cm})$ up to a maximum size of $50 \times 140 \times 50(\mathrm{~cm})$. To build the wall, locally produced blocks laid with a mortar were used [4].

The stones were baked in layers, one with the raw stone and the other with the tropical wood (coming from the neighbouring forests), forming a pyramid that reached the top of the kiln (Fig. 6).

Due to the use of tropical wood, the ecosystem was badly damaged, including the heating of the city and the instability of the land through cutting of trees; only from 1800 did Cartagena de Indias restore an ecological balance, when the use of the kilns was stopped.

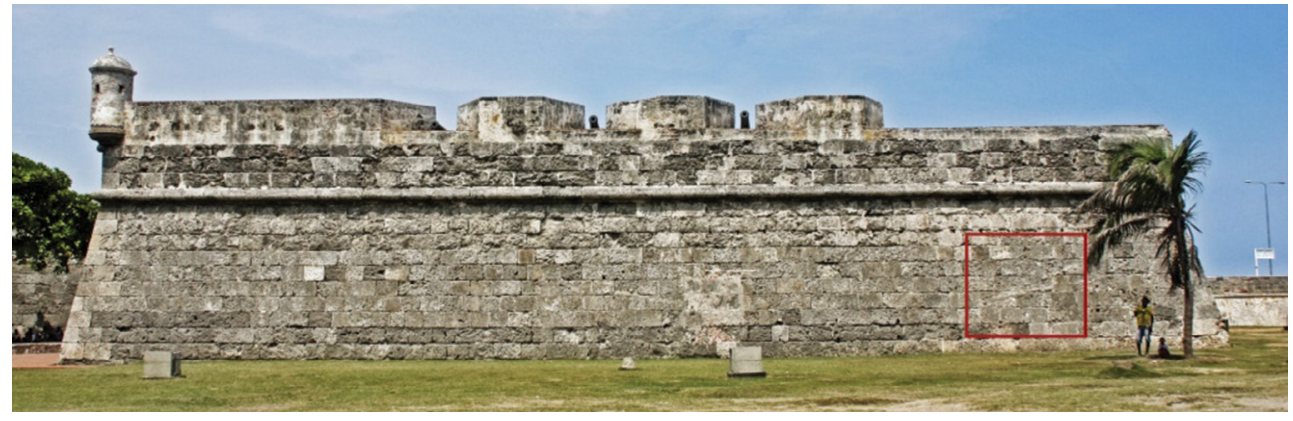

Figure 4: 'Santa Catalina' bastion. 


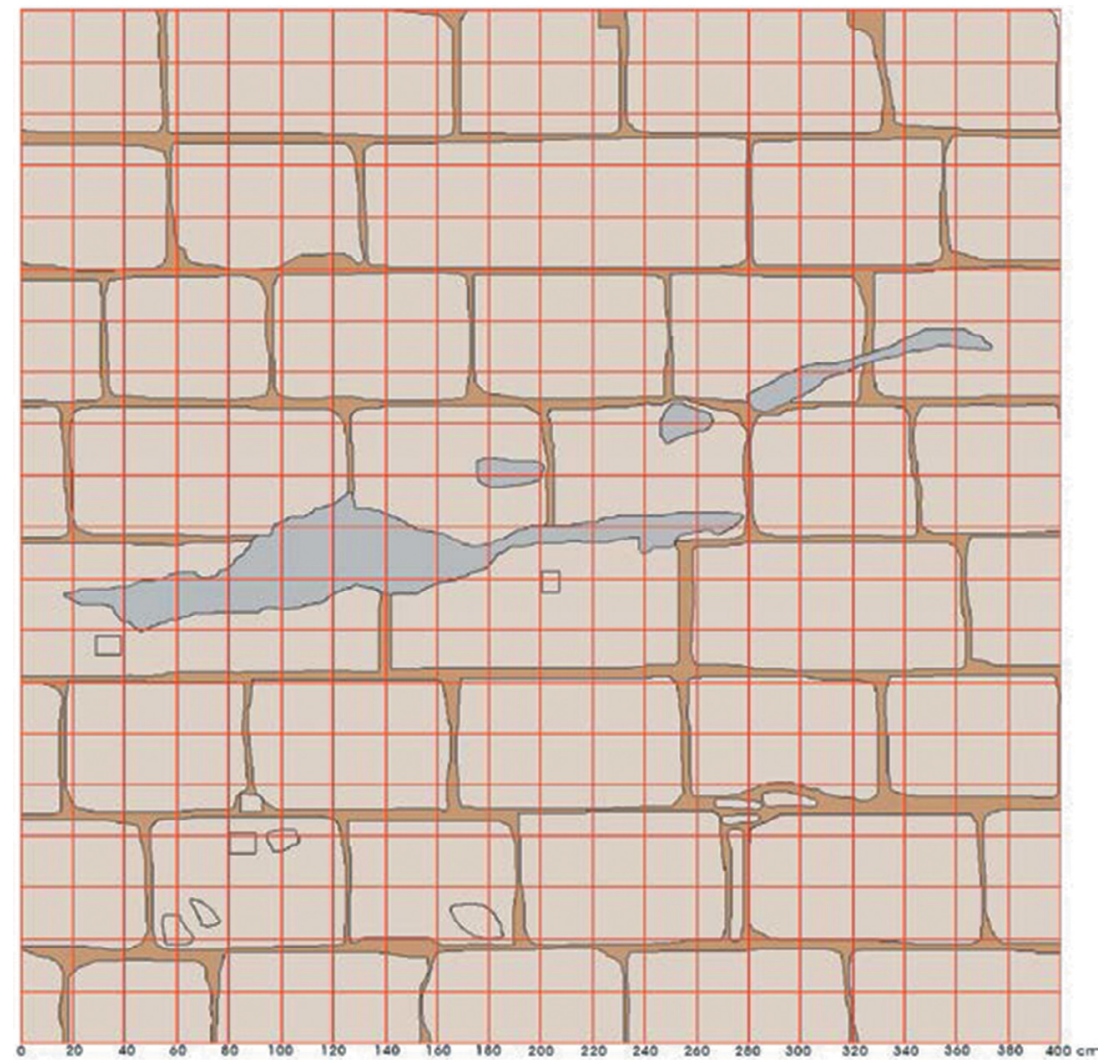

pietra $87 \%=$ malta $13 \%$

Figure 5: Technological characterization of the wall.

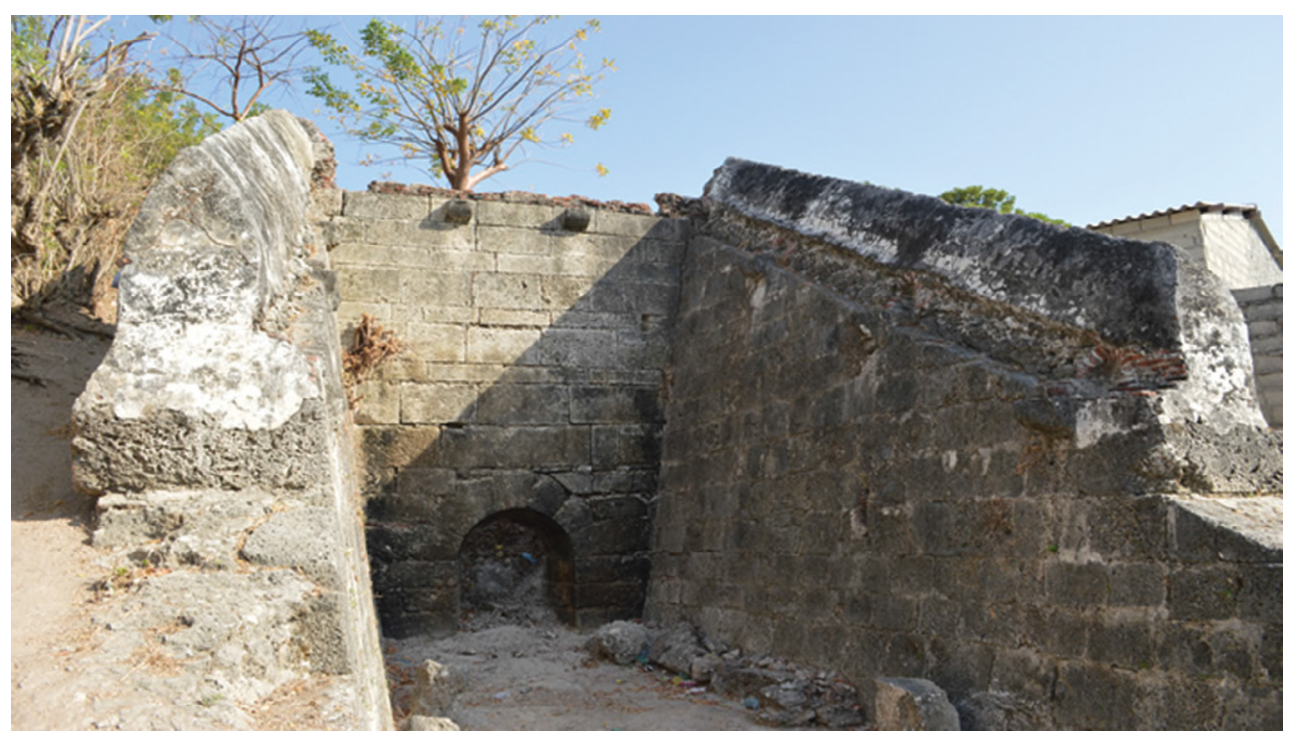

Figure 6: The kiln for baking the block. 


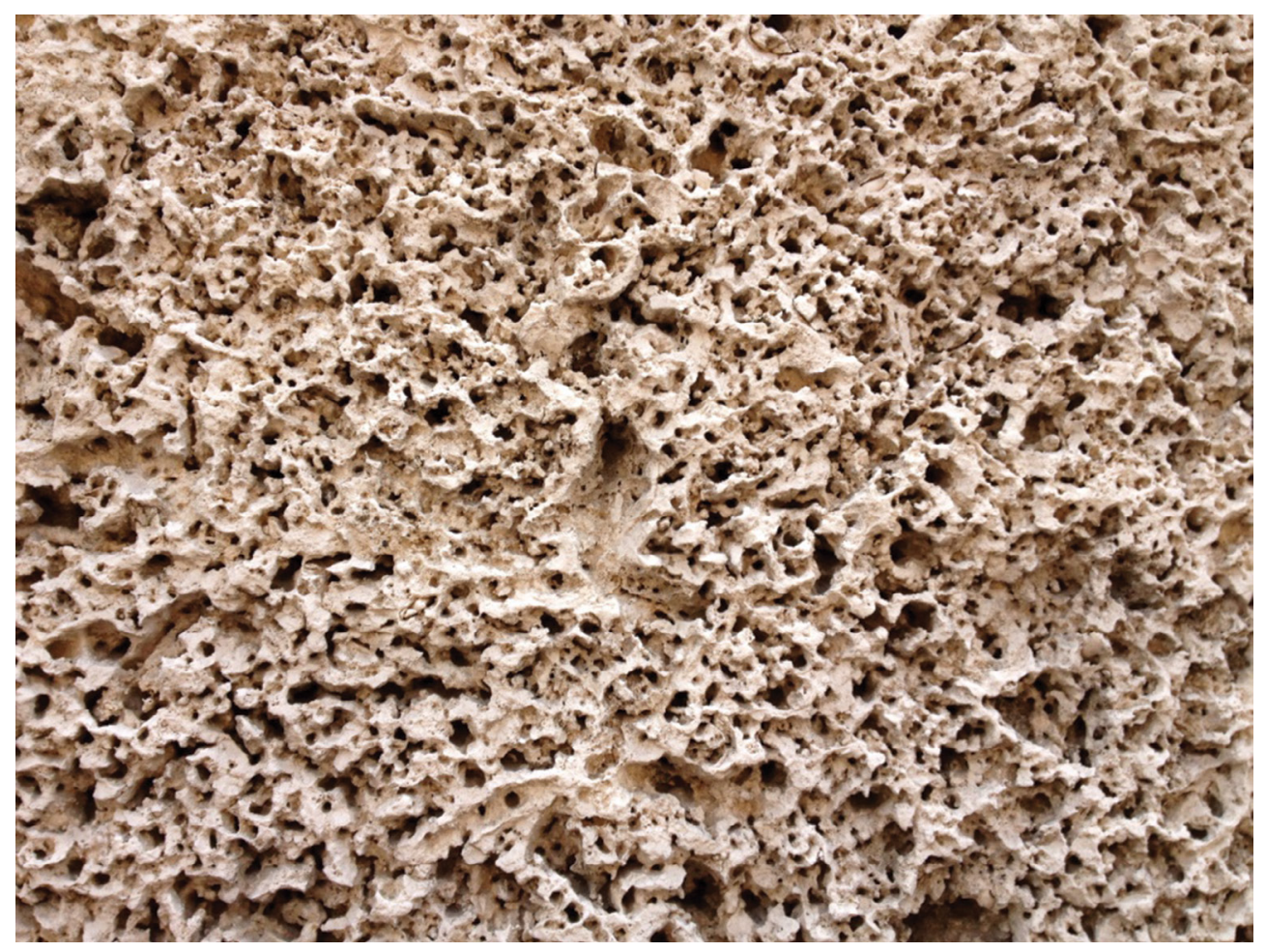

Figure 7: The degradation of the stone.

Today the wall extends to about $12 \mathrm{~km}$ almost perfectly intact in its geometrical shape and its constructional elements. It is possible to highlight different pathologies (alterations (as spots or patinas) and degradations) on the wall [5] (such as alveolization and erosion (Fig. 7) - more widespread because of the winds and high salinity of the air) and finally efflorescence.

The municipality guarantees just the maintenance of the wall (cleanliness and care of green spaces), but does not directly intervene in its restoration [6].

\section{THE WALL AND THE URBAN DEVELOPMENT OF THE CITY}

For three centuries the kilns constituted an important industry for Colombia; in fact, the most important city and defence systems were developed around the kilns [7]. In the beginning, the city grew and expanded rapidly without order and control; in this process some important parts of the ancient walls such as the part called 'Revellin de la Media Luna' and the wall that connected the 'Boca del Puente' (today called 'Torre del Reloj') to the bastion of 'San Pedro Martir' were demolished. In this way new neighbourhoods for noble families such as 'Manga' and 'Cabrero' grew, while the poor people built shacks (using wood and iron sheet) behind the walls: thus the popular neighbourhood called 'Getsemani', one of the most characteristic colonial styles of the city, grew. Cartagena underwent changes from the 17 th to the 19th centuries: it went from the golden age as defined by its wealth, for its thriving port, which has become one of the most important of the Caribbean coast until its decline that coincided with the end of the Spanish domination, thus becoming a republic.

In 1821, Cartagena de Indias was destroyed after the last battle against the Spanish and its population was reduced to 3,000 from its earlier total of 15,000 inhabitants. 


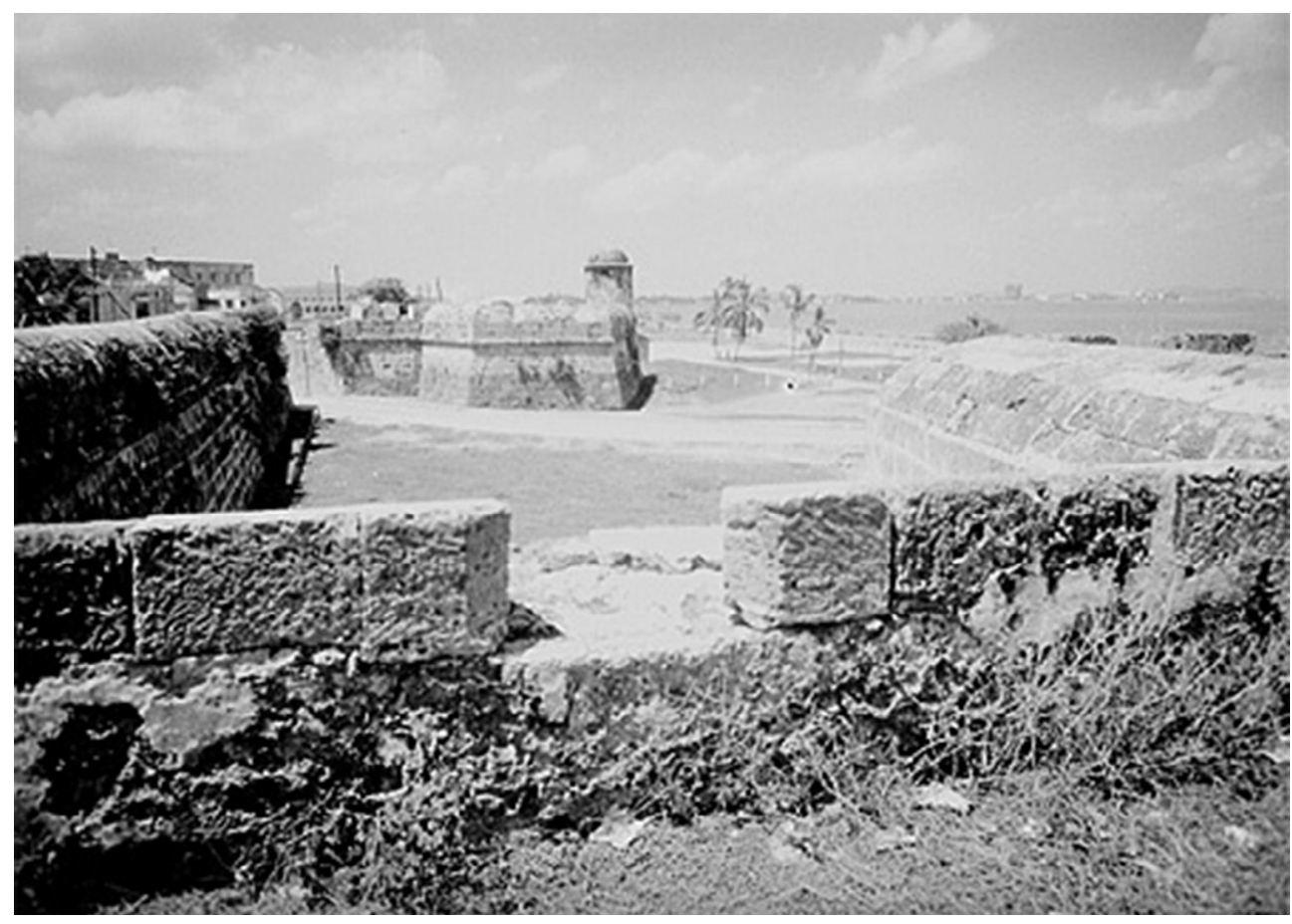

Figure 8: Historical image of the book 'Cartagena of Mangini'.

It was a tragic event that modified substantially the social and economic conditions of the city [8]. This situation caused the loss of the local workers and - with them - the loss of the original constructive techniques: the constructive history of the wall is a clear example of this revolution [9].

In fact, it is not possible to write of maintenance or restoration interventions for the wall in that period; the only interventions performed at that time looked like a 'patch' realized with different colours, materials and techniques of the original parts. The book 'Cartagena of Mangini' (Fig. 8) documents a city (from 1900 until the second half of the 19th century) that appears 'dysfunctional', 'old', 'consumed' with respect to the same city under Spanish rule: the 'favelas' built in the historic city centre was abandoned and in its place grew the new suburbs [10], the city expanded to the south and hinterland; the bay looked like an abandoned ruin.

\section{ZAPATERO'S INTERVENTION METHODOLOGY}

The Spanish historian Juan Manuel Zapatero [2, 3] studied and worked on recovery of the built heritage of Central-South America for many years, in particular he studied the entire defensive system of Cartagena de Indias by writing 'Las fortificaciones de Cartagena de Indias, para su estudio asesor restautación' and 'Historia de las fortificaciones de Cartagena de Indias'.

These handbooks recount in chronological order the evolution of building military fortresses of Cartagena from the first to the last intervention of the neoclassical period. The contribution of Zapatero will form the guidelines for the maintenance and conservation of the wall.

By dividing the entire wall into curtains and bastions, Zapatero lists the state of degradation in which it occurs and applies two principles to realize the interventions: restoration and 


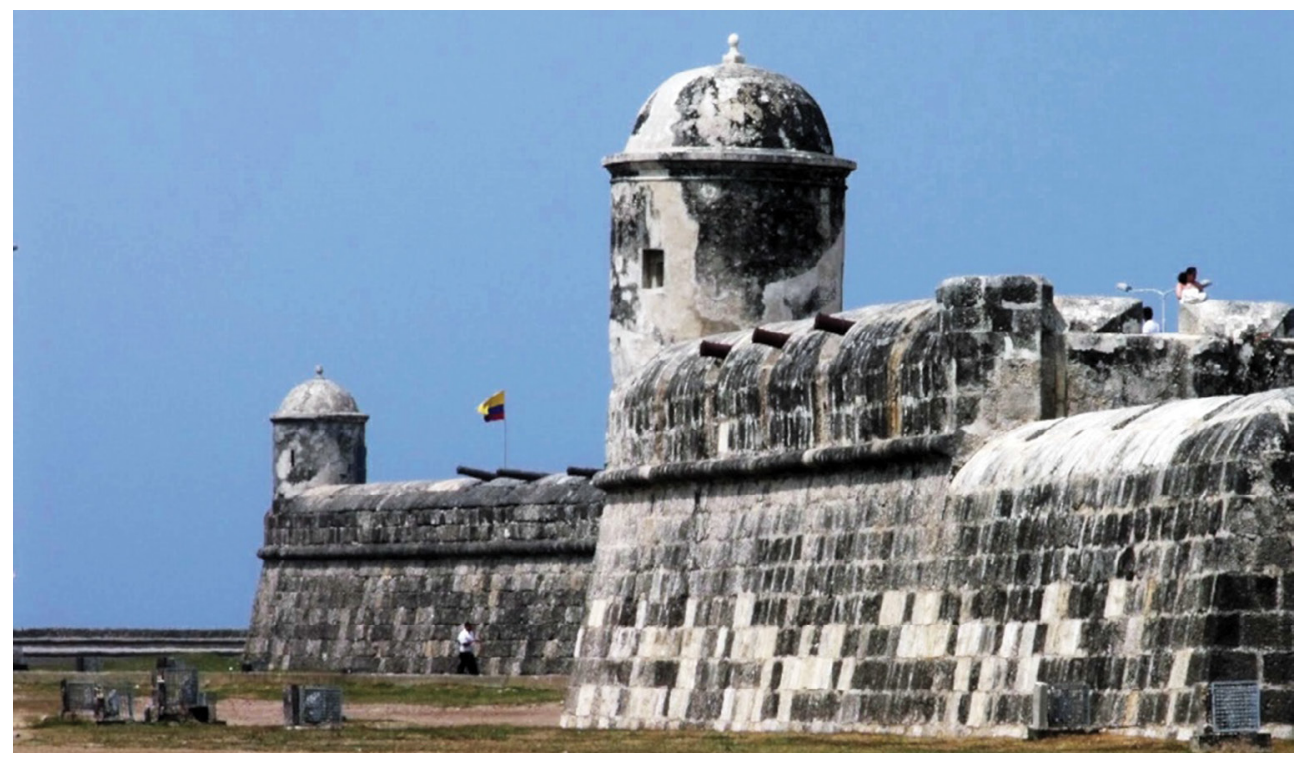

Figure 9: The sighting tower of the wall.

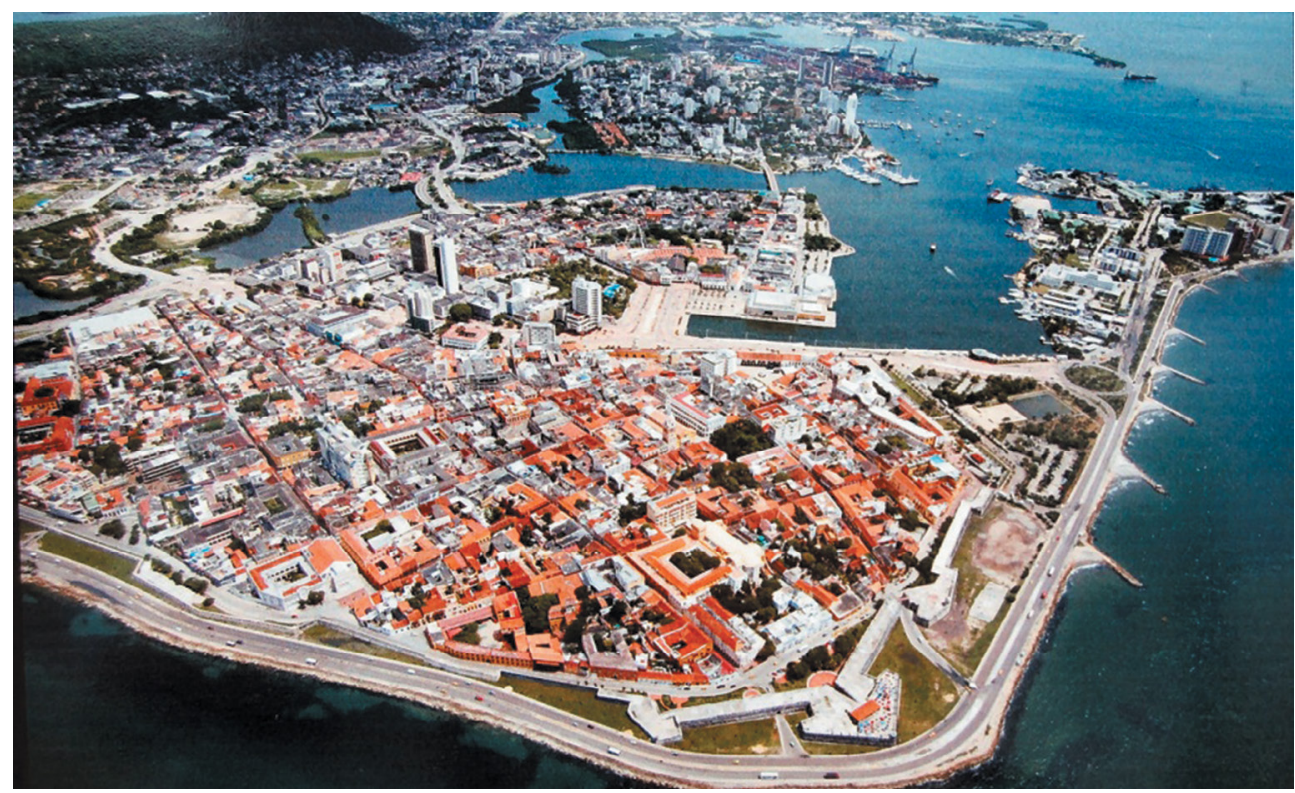

Figure 10: A view of Cartagena de Indias.

museological rehabilitation ('restauración y rehabilitación museological') [3]. The first principle is based on the hypothesis that an intervention can be applied based on pathological analysis; the second principle is based, instead, on the return of the missing characteristic elements of 'abaluartado', such as the inclusion of the sighting towers (Fig. 9), access ramps, the battlements or the 'tendal', sheds built for the soldiers to protect them from inclement weather. 
The second principle was more criticized at the Venice Charter for the restoration and preservation of monuments (1964), whose content regards the fundamental principles of the authenticity of built heritage (' $[\ldots]$ the conservation and restoration of monuments is to safeguard both the work of art than as historical evidence'), according to Cesare Brandi's idea of restoration that 'constitutes the methodological moment of recognition of the work of art in its physical form and the dual polarity and aesthetics historical, in view of its transmission in the future'. The idea of Zapatero conflicts with the principles of the Charter of Venice, as he proposes a 'false history' of built heritage, against the principle of authenticity.

The historic city centre of Cartagena de Indias, 'la Ciudad Amurallada', was declared a 'National Heritage of Colombia' in 1959 and has been included in the list of World Heritage Sites by UNESCO in 1984 (Fig. 10).

\section{CONCLUSIONS}

The analysis and knowledge of built heritage is very important for the contemporary debate on conservation intervention.

Historiographic reconstructions, structural analysis and material and technological characterization become the cornerstones of complex studies to outline the guidelines to define recovery interventions and preservative actions.

The research shows that Zapatero's methodological approach is still valid today, but it should be supported by a project of use for a social retraining: an architectural project can lead to excellent technical solutions, but a good design makes the community a part of this process. The preservation of a monument is not just its own conservation, in recognition of its historical and cultural value or in the characterization of its degradation. A monument could be used by the people, with a new awareness, that will ensure its survival - over time - of the historical memory of the past, the logic of the 'crystallization' of the monument in a museum of itself.

\section{REFERENCES}

[1] Segovia, R., Las forticaciones de Cartagena de Indias: Estrategía e historia, El Áncora Editores: Bogotá, 2009.

[2] Zapatero, J.M., Las fortificaciones de Cartagena de Indias: estudio asesor para su restauración, Banco Cafetero de Colombia: Madrid, 1969.

[3] Zapatero, J.M., Historia de las fortificaciones de Cartagena de Indias, Ediciones Cultura Hispanica Del Centro Iberoaméricano De Cooperación I Dirección General De Relaciones Culturales Del Ministerio De Asuntos Exteriores: Madrid, 1979.

[4] Carbonara, G., Trattato di restauro architettonico, UTET: Torino, vol. II, 1978.

[5] Binda, L., Metodi statici di stima della capacità portante di strutture murarie. Comportamento statico e sismico delle strutture murarie, (a cura di) G. Sacchi Landriani, \& R. Riccioni, Clup: Milano, 1982.

[6] Mastrodicasa, S., Dissesti statici delle strutture edilizie, Hoepli: Milano, 1988.

[7] Cabrera, A., Martelo, R., Torres, L., Samudio, A., Catalá, J., \& Piñón J.L., Cartagena de Indias. Pasado, presente y futuro, Editorial de la UPV: Valencia, 2003.

[8] Blanes, T., Fortificaciones del Caribe, Editorial Letras Cubanas: Cartagena, 2001.

[9] Lemaitre, E., Bossa Herazo, D., \& Sebá Patrón, F., Historia general de Cartagena, 3rd ed. El Ácora Editores: Bogotá, 2011.

[10] Magre, A., Colorado, A., \& Lara, M.I., La Cartagena de Mangini, fotografie di Giovanni Mangini, Dematinada: Bogotà, 2010. 